University of Nebraska - Lincoln

DigitalCommons@University of Nebraska - Lincoln

20th \& 21st Century French and Francophone Modern Languages and Literatures, Department Studies International Colloquium

$4-2020$

\title{
Expropriation and Forced Migrations: The Displacement of Colonial Agricultural Laborers in Mohammed Dib's Algerian Trilogy
}

Benjamin Sparks

Follow this and additional works at: https://digitalcommons.unl.edu/ffsc2020

Part of the Comparative Literature Commons, French and Francophone Literature Commons, and the Other French and Francophone Language and Literature Commons

This Article is brought to you for free and open access by the Modern Languages and Literatures, Department of at DigitalCommons@University of Nebraska - Lincoln. It has been accepted for inclusion in 20th \& 21st Century

French and Francophone Studies International Colloquium by an authorized administrator of DigitalCommons@University of Nebraska - Lincoln. 
doi: 10.32873/unl.dc.ffsc.09

20th \& 21st Century French and Francophone Studies International Colloquium, University of Nebraska-Lincoln, March 26-28, 2020.

https://digitalcommons.unl.edu/ffsc2020/

Copyright ( 2020 Benjamin Sparks

Expropriation and Forced Migrations: The Displacement of Colonial Agricultural Laborers in Mohammed Dib's Algerian Trilogy

\author{
Benjamin Sparks \\ University of Memphis
}

Pierre Bourdieu argues that the colonization of Algeria achieved its success through the expropriation of land through the Senatus Consulte of 1863, along with the Warnier Law of 1873. Before these laws, however, the initial colonization of Algeria in 1830 began to alter and disrupt traditional society; before the conquest of Algeria by the French, Algeria consisted of many tribal entities which at the time were attempting to fight off the Turks. As the French came in, they either dispossessed or killed off the tribal chiefs who acted as the guardians of tradition, and keepers of treasures. In doing so, the newly instated colonizers expropriated the former Chiefs' land. The expropriation of land by the colonizer began with the initial colonization but progressed further with the arrival of a more extensive European settler population. The Senatus Consulte and Warnier laws continued this expropriation allowing for the regular transfer of lands to settlers under a legalistic façade. To the unassuming eye, the Senatus Consulte of 1863 appeared to be pro-Arabe; the first article states that the Algerian tribes are declared owners of the land, which they traditionally held. What made the Senatus Consulte pro-French was the 
transformation of communal property into private property, a commodity available for sale or purchase, which disrupted the traditional tribal society. This transformation also allotted newlyarrived settlers land, which was often the most arable. With the distribution of private property came the inequalities of a capitalist society, creating a class distinction between wealthy and poor, something that had not entirely existed previously.

Mahfoud Bennoune states that "since this law stipulated that unproductive and uncultivated lands must be claimed by the French office of colonisation as belonging to the state, the Commissaires-Enquêteurs in charge of these operations considered innumerable hectares of fallow field as uncultivated or vacant, and thus assigned them arbitrarily to the Domaine" (46). These laws achieved the colonial endeavor's penultimate goal through the "destruction of the fundamental structures of the economy and of the traditional society" (Bourdieu, Le déracinement 120). Oyamad Noriko similarly argues that the ultimate objective of the land policies was to establish private land ownership, and that, to do so, it was necessary to "dismantle the tribal organizations of natives who resisted colonization and weaken the resistance of the tribe by annihilating communal landownership while at the same time ease the transition of land to European settlers by establishing private landownership on tribal areas" (17).

These laws allowed for the systematic spoliation of the rural communities and the destruction of traditional society. They initially forced the agricultural labor onto less arable lands, but when these tracts would not produce sufficiently, the laborer was obligated to migrate to the urban center and rely on the charity of others or to find employment working the lands of the colonizer as a reserve of cheap labor. As a result, the colonized experienced a collective trauma, one that is a "blow to the basic tissues of social life that damages the bonds attaching people together and impairs the prevailing sense of communality" (qtd. in Alexander 4). 
Unfortunately for the colonized, with a growing population and modern technology employed by the colonizer, it became difficult to find a proper, consistent, wage-earning source of employment.

Germaine Tillion, a French ethnologist, provides a pro-colonialist perspective on the expropriation of land and resources by arguing that, "with its outdated methods of cultivation, the country is capable of feeding between two and three million people" (3) while the population far exceeded nine million. She, thus, argues that the French, theoretically to help the Algerian populace, expropriated the land to introduce modern methods of cultivation, as well as a more productive labor workforce. This pro-colonialist view fails to take into account the unequal redistribution of wealth, forcing the majority of the population off their lands and into poverty, rather than coming to their aid. With the expropriation of land and the French technology to convert untillable land through irrigation and drainage, the colonizer gained a larger slice of the agricultural pie (Horne 62).

Laroussi Khelifa, Algeria's Minister of Industry and Energy under the first government of Ben Bella from September 1962 to September 1963, argues in his Manuel du Militant Algérien that before the arrival of the French colonists, Algeria prospered agriculturally. Khelifa, to prove his point, cites Jacques Philippe Laugier de Tassy in his Histoire des Etats

Barbaresques by declaring that,

la Campagne d'Alger est plus belle et très fertile en légumes, en fruits et en fleurs. Ses plaines et ses collines bien cultivées, offrent une agréable diversité à la vue. [...] Derrière la côte orientale de la montagne, se trouve une autre plaine baignée de plusieurs ruisseaux. Elle est abondamment peuplée de tribus arabes. C'est ici la plaine de la Mitidja. Elle produit deux à trois moissons de froment, d'orge, d'avoine, de légumes... (Khelifa 59).

Khelifa goes on to argue that with the onset of colonization and expropriation that "notre économie riche et varié a été impitoyablement refoulée à l'état d'une économie de simple 
subsistance ; notre peuple a été réduit à la misère et à la régression par les vols de toutes ses richesses opérés [sic] par les colonialistes français" (61).

Mohammed Dib, in his Algerian trilogy, demonstrates the effects of expropriation and mendicancy on the patterns of migration of agricultural laborers, illustrating the historical context of colonial Algeria through the act of storytelling. Mohammed Dib in 1949 devised the idea to write "un roman aux proportions assez vastes qui devait présenter une sorte de portrait divers de l'Algérie" (Déjeux 145) which would later become what constitutes the Algerian trilogy consisting of La Grande maison published in 1952, L'Incendie in 1954, and finally Le Métier à tisser in 1957. The trilogy tells the story of Omar's upbringing in colonial Algeria surrounded by inevitable suffering and war as the veil shielding him from the reality of life falls from before his eyes. The trilogy begins with Omar as a ten-year-old boy living in Dar-Sbitar, a run-down hospital that has now become the residence for the poor of Tlemcen and referred to as la grande maison, with his mother and two sisters. His mother desperately and tirelessly works to provide food for her children but often comes up empty-handed. Dib's opening novel displays the harsh conditions of not only the adults in this Manichaean world but of the children as well. The following book, L'incendie, continues Omar's narration as he travels to Bni Boublen, a village in the Algerian countryside, with Zhor, a neighbor from Dar-Sbitar. In Bni Boublen, Omar, as an observer and witness, describes the horrible conditions of the fellahs who have become dispossessed of their lands and have become a resource of cheap labor for the Europeans. He also becomes a witness to the prise de conscience of the fellahs in which emotions run high and result in not only a strike, but also an incendie, which symbolizes the fellahs' fervor and, thus, cannot be extinguished. The final novel of the trilogy, Le métier à tisser, continues to follow the story of Omar, who is now fourteen years old and has left school 
and become an apprentice weaver. This novel demonstrates that the prise de conscience that had occurred in the countryside likewise has taken place back in the urban centers of Tlemcen.

Jean-Robert Henry argues that land is an integral element in the Algerian colonial literature as it is "à la fois comme base de la colonisation [sic] et comme lieu du conflit colonial" (157). The theme of dispossession and expropriation are central to the last two novels of the Algerian Trilogy, L'incendie, and Le métier à tisser. The fellahs make simple remarks throughout $L$ 'incendie, almost in passing, referring to the expropriation of lands by declaring: “Des étrangers possèdent le pays" (Dib, L'incendie 67). In speaking of Bni Boublen, Comandar argues that only a hundred years before no one inhabited this region, but one by one les anciens settled the area because the colonizer had forced them off their old lands. Before the initial establishment of Bni Boublen, the fellah had "des terres à orge, à figuiers, à maïs, à légumes et à oliviers," but through expropriation “elles leur furent enlevées” (64).

The narrator aptly describes the expropriation of land in L'incendie as he declares: "Des hectares par milliers devenaient la propriété d'un seul colon. Celui-ci ou cet autre, c'était pareil : ils étaient arrivés dans le pays avec des chausses trouées aux pieds. On s'en souvenait encore par là. Ils possédaient à présent des étendues incalculables de terre," which contrasts greatly with the fellahs who "de génération en génération, suaient pendant ce temps-là sang et eau pour cultiver un minuscule lopin" (Dib, L'incendie 31). The colonizers possess a significant portion of the land which they have taken from the colonized, leaving the colonized with plots which are either too small or are infertile, or worst of all, a combination of both. Ben Youb, a fellah, slowly begins to recognize the injustices and suffering as a result of the expropriation of land. He concludes that "la véritable richesse était rassemblée entre les mains des colons" (Dib 31). Ben Youb's unfortunate plot of land does produce, but its location on the foothills leaves much to be 
desired. Of Youb's land, the narrator states, "Lui, sa terre ne commençait, comme celle des autres cultivateurs de Bni Boublen, que sur les flancs anguleux de la montagne. Cette terre produisait, mais, comme les femmes de ces hauteurs, toutes en gros os, elle donnait un lait rare" (31). Ben Youb, however, is not the only one who has been forced to cultivate "au seuil de la steppe" (31), on the land considered unsuitable by the colonizer and, thus, left to the colonized.

With the expropriation of land, the fellah, who have decided to leave the miserable plots of land, the colonizers' leftovers, immigrate to the urban centers. Through the narration of $L e$ métier à tisser, the displaced mendicants express, through their silence, the suffering, and trauma of colonial oppression. In this novel, the urban center has become overrun with the homeless, unemployed population from the countryside. Azzedine Haddour describes the historical context as she states, "Eighty-five per cent of a sedentary population was reduced to a nomadic life and many peasants were forced to immigrate to Tunisia, Morocco, or the Middle East" (113) as a result of expropriation. Bourdieu similarly argues that,

The disintegration of the agrarian order has led to an abnormal development of the cities. Life appears to have nothing stable or durable to offer the urban populace, which has been completely and irrevocably cut off from its former environment, lives crammed together in incredible densities in the unsanitary dwellings of the old city districts or of the new shantytowns, and is generally filled with uncertainty as to the future. The misery and insecurity have been made even worse by the distress resulting from the loss of the group ties on which the individuals' psychological and social stability was based in the old communities. (The Algerians 141)

The actual urban effects of the colonizer's actions in the countryside become evident through the sizeable mendicant population.

These vagrant individuals are like phantoms and zombies; they are the walking dead who haunt the living: "Lentement, leur foule, hommes, femmes, vieillards, enfants, prenait possession de tous les quartiers. La plupart d'entre eux étaient valides" (Dib, Le métier 14). These vagabonds, as described by Dib, are neither invalid nor outcasts to society; they have merely 
been displaced, comparable to refugees, with no place to go. They become beggars, forced to rely on the charity of others, or starve as a result of the unemployment rate for unskilled laborers. Day by day, the number of beggars who enter the concrete jungle increases with little waiting there for them. The mendicants set up wherever is convenient as Dib's narrator aptly describes the situation: "On en découvrait de plus en plus au fond des impasses, sous les auvents, aux abords des remparts, devant les bains publics, sur les escaliers du marché couvert, au pied des murailles turques de Méchouar, contre le porche des fondouks. Dans toutes les rues déambulaient leurs silhouettes mal ficelées, grises et sales" (15).

Dib intertwines the narration of the life of Omar with the introduction of these mendicants as a form of social realism, an illustration of the Algerian identity under colonialism, which then constructs collective trauma. The wounds of colonialism have altered, battered, and buried the Algerian identity in irrevocable ways. It has been a form of shock, "a gradual realization that the community no longer exists as an effective source of support and that an important part of the self has disappeared" (qtd. in Alexander 4). Similarly, the narration of Omar's story, intermingled with the story of the mendicants, reinforces the mutual sharing of suffering as social and collective trauma. Initially, Omar and the other city dwellers fail to understand the mendicants, viewing their pain as individual, not existing outside of the mendicants' realm. For this reason, the narration's preoccupation with the vagrant population transforms the mendicants' suffering from personal to collective; "Ce ne sont que les nôtres. Hé! Regardez-les ; comme un miroir, ils vous renverront notre propre reflet. L'image la plus fidèle de ce que nous sommes, ils vous la montrent !" (19). They are a reflection of the general population who suffer under the hands of the colonizer. 
The narrator aptly describes these individuals as "des meurt-de-faim" (18), who are no different than Omar and his family. Omar, during the year between working at the épicier and being hired on as a dévideur, someone who winds up loose string, such as yarn or wool which has already been spun, into a ball that can then be used to make clothing or rugs, acts no differently than the mendicants who "vagabondaient un peu de-ci, de-là ; jamais ils n'allaient bien loin. Inattentifs les uns aux autres, ils ne se réunissaient pas entre eux. Mais quand, quelque part, une distribution de nourriture ou de gros sous avait lieu, ils formaient un cercle qui s'enflait à vue d'œil" (18). After being hired by Mahi Bouanane as a dévideur, Omar distances himself from the mendicants, as he can now provide at least minimal amounts of food for himself; he, however, still acts as an observer to objectively portray the growing suffering. As an observer, Omar ventures among the masses of vagrants as the narrator notes that "Les rues étaient encombrées de mendiants, si bien qu'en maints endroits, il devait enjamber des corps pour passer" (44). Due to high unemployment and expropriation, vagrant humans now replace these places, once littered with goats. The replacement of goats with mendicants demonstrates the colonial regime's lack of concern for the displaced, equating them with animals. After having observed and walked among these mendicants, Omar decides to interact with them. These hordes of beggars, zombie-like creatures, haunt Omar's conscience, and he chooses to share some bread and fish with a little girl among the crowd. Once the girl has eaten her share, the father is left standing with the crumbs that remain. All the other beggars stare blankly at the father, unsure what to do with the remnants. Omar realizes that he has just stirred the pot; he has momentarily awakened the walking dead and flees in fear. Omar realizes that with the growing population of these mendicants, it becomes more and more challenging to appease them with such limited means. 
With each new description of the city of Tlemcen by the narrator in Le métier à tisser comes an update on the status of the mendicants. Aïni, Omar's mother, notes the increasing amounts of beggars as she declares that, "Des mendiants arrivent de partout, ces jours-ci" (Dib, Le métier 41). Described as having "des visages brûlés, secs. C'étaient des femmes, à la féminité sacrifiée, assises sur les trottoirs ou les marches des magasins ; des hommes, debout, couchés, pliés en deux, cachant les mains sous leurs guenilles" (44). As the novel progresses, the number of beggars increases, while at the same time, the general population becomes numb to their presence; the narrator argues that "A bout de patience, les habitants firent comme si ces êtres n'existaient pas, et ne s'occupèrent plus d'eux. [...] Au surplus, des agents de police étaient postés à tous les coins de rue" (Dib 117). Once the horde of mendicants has grown too large, neither the colonizer nor the colonized can help. The colonizer instead attempts to suppress the mendicants through a visible policing force, while the colonized continue with their mundane daily routine. As a result, the mendicants have affected the colonized, causing them to become not only numb to the beggar's suffering, but their own as well.

The fellahs' migration from the countryside to the urban center as a result of expropriation and forced migration highlights the suffering of the colonized through the colonizer's actions. Dib's representation of the socio-historical climate through storytelling demonstrates the impact of these decisions on the Algerian mindset, whether leading to despair or hope, death, or revolution. 
Works Cited

Alexander, Jeffrey C. Trauma: A Social Theory. Cambridge, UK: Polity, 2012.

Bennoune, Mahfoud. The Making of Contemporary Algeria, 1830-1987: Colonial Upheavals and Post-independence Development. Cambridge: Cambridge UP, 1988.

Bourdieu, Pierre, and Abdelmalek Sayad. Le déracinement: La crise de l'agriculture traditionnelle en Algérie. Paris: Les Éditions De Minuit, 1964.

Déjeux, Jean. Littérature maghrébine de langue française: Introduction générale et auteurs. Sherbrooke: Naaman, 1978.

Dib, Mohammed. La grande maison. Paris: Seuil, 1996.

---. Le métier à tisser. Paris: Seuil, 2001.

---. L'incendie. Paris: Seuil, 1989.

Haddour, Azzedine. Colonial Myths: History and Narrative. Manchester: Manchester UP, 2000.

Henry, Jean-Robert. "Roman colonial et idéologie coloniale en Algérie." Revue algérienne des sciences juridiques économiques et politiques XI.1 (1974): 157-66.

Horne, Alistair. A Savage War of Peace: Algeria, 1954-1962. New York: Viking, 1978.

Noriko, Oyamada. "The 1873 Warnier Law and the Formation of Private Landownership in Algeria: The Transfer of Landownership from Indigenous Peoples to European Settlers." The Journal of Sophia Asian Studies 30 (2012): 15-40.

Tillion, Germaine. Algeria: The Realities. Trans. Ronald Matthews. New York: Alfred A Knopf, 1958. 
